Станович О. В.';

Клевко П. В.';

Цимбал I. В. ${ }^{1}$;

Плугова О. Б. ;

Троцько Л. Г.

Ворона Т. O. ${ }^{2}$

1 - Військовий інститут телекомунікацій та інформатизації, Київ;

2 - Центр воєнно-стратегічних досліджень Національного університету оборони України імені Івана Черняховського, Київ

\title{
Методичний підхід до обгрунтування раціонального варіанта забезпечення Збройних Сил України новими зразками військової техніки в сучасних умовах
}

Резюме. У статті запропоновано підхід до вибору варіанта забезпечення новими зразками військової техніки для оснащення Збройних Сил України з урахуванням впливу ряду системних факторів. Як спосіб оцінювання варіантів запропоновано метод аналізу мереж (AHP-process).

Ключові слова: методичний підхід, військова техніка, Збройні Сили України, метод аналізу мереж (AHP-process), антитерористична операція.

Постановка проблеми. Забезпечення Збройних Сил України (далі - ЗС України) сучасними зразками військової техніки (далі ВТ) в сучасних умовах $є$ одним 3 основних завдань воєнно-технічної політики держави. Досить тривалий період, починаючи 3 90-х років минулого сторіччя, темпи оснащення ВТ ЗС України суттєво відставали від потреб. У результаті на сучасному етапі велика кількість ВТ української армії потребує оновлення. Ряд зразків, які були на озброєнні армії колишнього СРСР, на сьогодні здебільшого $\epsilon$ морально застарілими і за своїми бойовими можливостями не можуть задовольнити вимоги до ведення бойових дій в сучасних умовах. Крім цього, із здійсненням агресії проти України в 2014 році з боку Російської Федерації та іiі переростанням у гібридну війну, яка продовжується існує необхідність у забезпеченні ЗС України значною кількістю ряду новітніх зразків ВТ.

Аналіз останніх досліджень i публікацій. $\mathrm{y}$ роботах вітчизняних i зарубіжних фахівців це питання вирішувалось здебільшого в контексті оптимізації технічних параметрів зразків ВT, 3 метою воєнноекономічного обгрунтування чи аналізу воєнно-технічної політики окремих держав [14]. Питання, що стосуються політики забезпечення або оснащення було другорядним. Нині, в умовах, коли інші держави (у тому числі й найближчі сусіди
України) активно оновлюють військову техніку, доцільно прискіпливіше звернутися саме до питання забезпечення.

Метою статті $\epsilon$ обгрунтування раціонального варіанта забезпечення ЗС України новими зразками ВТ.

Виклад основного матеріалу. Під терміном “забезпечення" у статті розуміється політика отримання необхідної кількості зразків ВТ певного типу для виконання завдань, що стоять перед ЗС України. Ця політика передбачає не тільки виробництво вітчизняних зразків ВТ але і закупівлю, спільне виробництво та виробництво за ліцензією.

У конкретному випадку, коли стоїть завдання вибору певного варіанта забезпечення 3 наведених, стосовно одного зразка ВТ (особливо якщо він $\epsilon$ складною технічною системою) необхідно враховувати дію наступних факторів:

- можливості вітчизняної промисловості 3 організації виробництва зразка, як за замкненим циклом, так i в кооперації 3 підприємствами інших держав;

- можливості держави 3 фінансування 3 розроблення та випуску, закупівлі тощо зразка BT;

- наявність виробництва аналогічних або подібних зразків ВТ в інших державах;

- науково-технічний потенціал держави, здатний забезпечити розроблення, 
випробування та використання нового зразка BT;

- вплив нового зразка ВТ на зміни в характері збройної боротьби.

Із перелічених факторів зрозуміло, що для їх врахування під час обгрунтування необхідне залучення експертних методів оцінювання (оскільки більшість факторів мають якісний характер) до яких належить, зокрема, метод аналізу мереж (далі - MAM), запропонований Т. Сааті [5-6]. Перевага цього методу перед іншими, i, зокрема, перед методом аналізу ієрархій $\epsilon$ можливість поєднувати експертні судження із системним представленням рішення певної наукової задачі, що передбачає використання не тільки міжелементних (міжгрупових), але i зворотних зв' язків.

Запропонований методичний підхід складається 3 таких етапів:

Перший етап. Визначення в кожному із перерахованих факторів груп (кластерів) показників за якими буде проводитися оцінювання та відповідних альтернатив. До таких груп можуть відноситися.

Можливості вітчизняної промисловості з організації виробництва зразка, як за замкненим циклом, так $i$ в кооперації 3 підприємствами інших держав:

- відсутні (В) - у державі ніколи не вироблялись подібні зразки ВТ і відсутні промислові потужності для створення їх виробництва;

- обмежені (O) - у державі є промислові потужності для виробництва подібних зразків ВТ, але вони потребують певного дообладнання або переобладнання;

- наявні $(\mathrm{H})$ - у державі наявні промислові потужності для організації виробництва зразка.

Можливості держави з фінансування 3 розроблення та випуску, закупівлі тощуо зразка ВT:

- відсутні (Bi) - держава не здатна фінансувати не тільки розроблення але i виробництво зразка ВТ;

- обмежені (Об) - держава може фінансувати виробництво обмеженої кількості зразків, або закупівлю їх частини за кордоном та частково інші варіанти забезпечення (лізинг, спільне виробництво);

- достатні (Д) - держава може здійснювати фінансування в повному обсязі такого зразку ВТ.

Наявність виробництва аналогічних або подібних зразків ВТ в іниих державах:
- відсутнє (Від) - в інших державах відсутнє виробництво подібних зразків ВТ (хоча прототипи або дослідні зразки можуть існувати);

- модернізація (M) - в інших державах здійснюється модернізація існуючих зразків ВТ 3 метою доведення їх тактико-технічних характеристик до рівня зразка, яким необхідно забезпечити 3С України;

- створення (С) - в інших державах створюється і випробовується новий зразок ВТ.

Науково-технічний потенціал держави, здатний забезпечити розроблення, випробування та використання нового зразка $B T:$

- наявність конструкторських бюро (Кб) в Україні існують конструкторські бюро (школи), укомплектовані фахівцями та випробувальна база для розроблення зразка ВТ; - наявність підготовлених фахівців (Ф) - в Україні відсутні конструкторські бюро, але існують фахівці та випробувальна база для розроблення зразка ВТ;

- наявність випробувальної бази (Вб) - в Україні наявна тільки випробувальна база для нового зразка.

Вплив нового зразка ВТ на зміни в характері збройної боротьби:

- незначний $(\mathrm{He})$ - новий зразок ВТ незначним чином вплине на характер збройної боротьби, поліпшуючи окремі бойові якості старих зразків;

- суттєвий (Су) - новий зразок ВТ вплине на характер збройної боротьби і вимагатиме відповідного переоснащення від інших технічних систем;

- корінних (К) - новий зразок ВТ призведе до зміни тактики або стратегії збройної боротьби.

Серед альтернатив, які дочільно розглянути під час обгрунтування можуть бути такі:

розроблення i подальше виробництво нового зразка в Україні (Р);

спільне 3 іншою країною розроблення $\mathrm{i}$ виробництво нового зразка в Україні (Св);

закупівля нового зразка за кордоном (3); виробництво нового зразка в Україні за ліцензією (Л).

Другий етап. Побудова мережі за визначеними групами та альтернативами. Ця мережа може містити прямі та/або зворотні зв'язки між кластерами, а також зв'язки всередині самих кластерів [5]. Вигляд такої мережі для описаних на першому етапі кластерів показаний на рис. 1. 


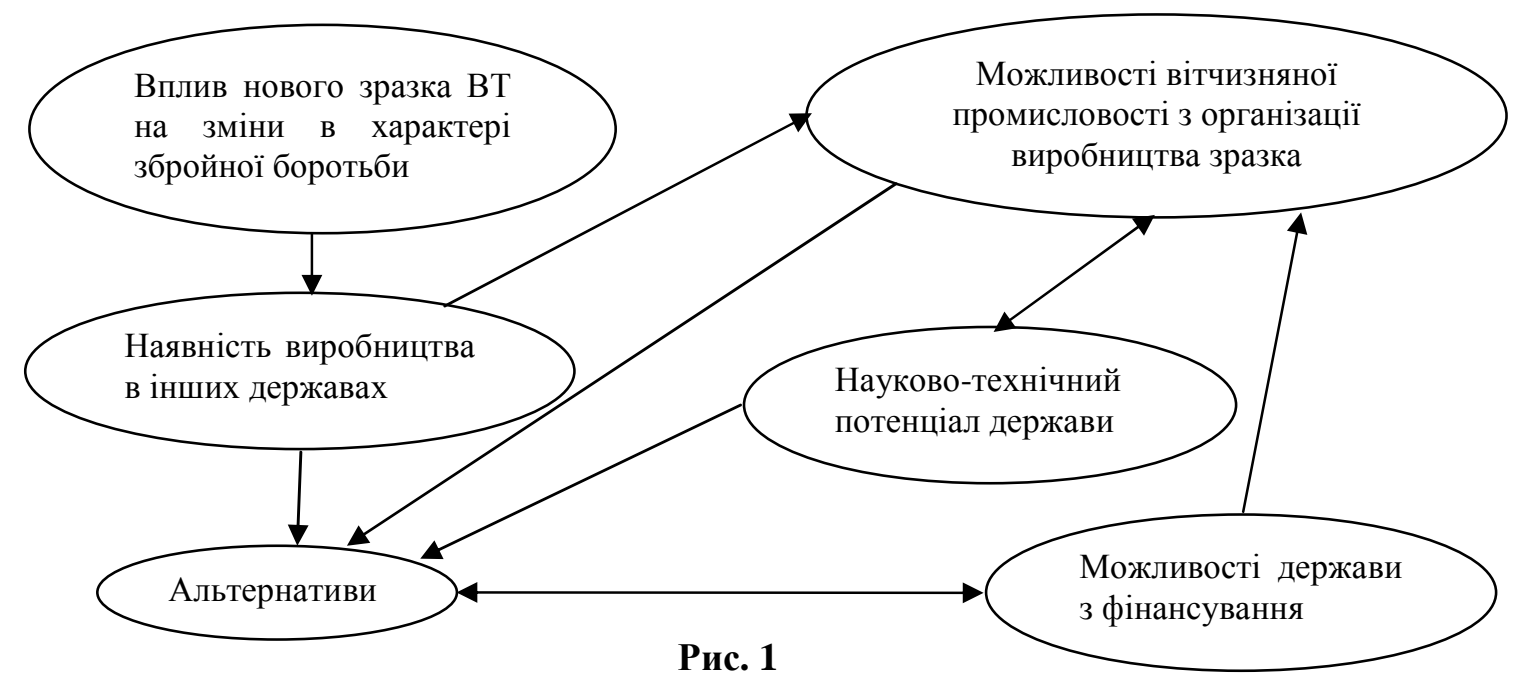

Показана на рис. 1 мережа не $€$ Слід зазначити, що мережа, наведена на рис. 1, універсальною для всіх зразків ВТ і може має спрощений вигляд. Повний вигляд зв'язків мати інший вигляд відповідно до специфіки у ній наведено на рис. 2.

розроблення або особливостей самого зразка.

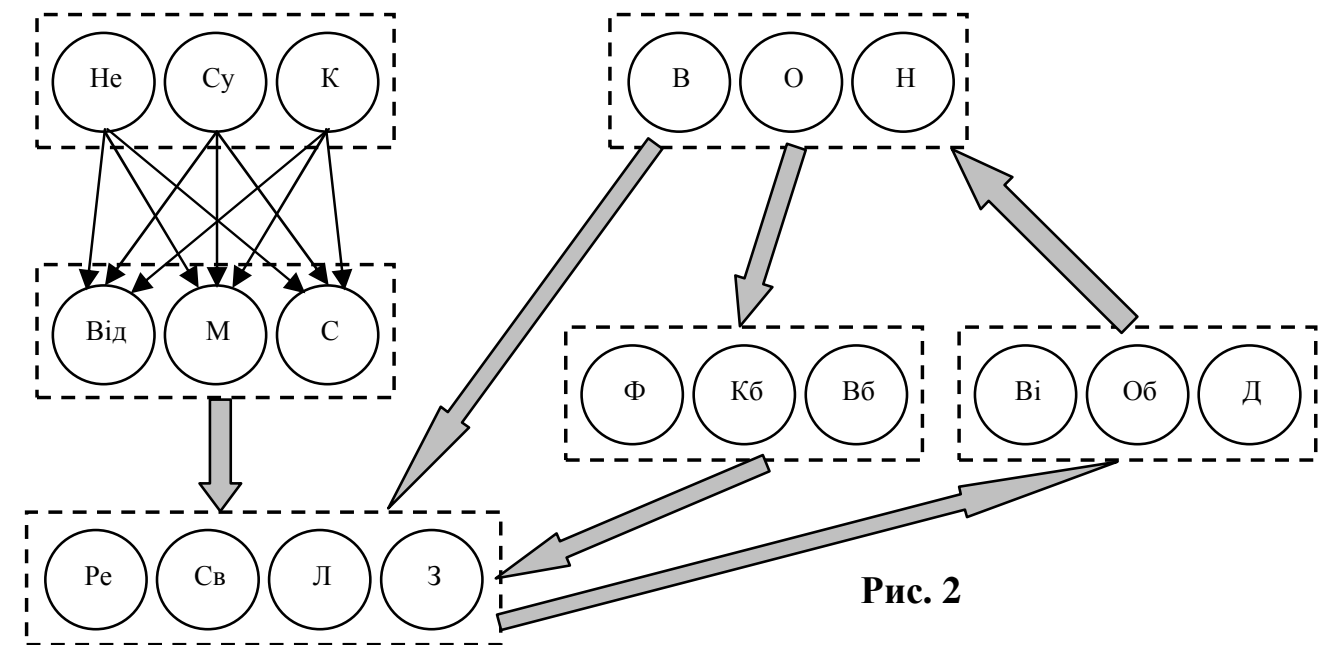

Однак, як правило, потреби в зображенні таких мереж не існує, або вони зображуються таким чином лише в окремих випадках для детальнішого пояснення зв'язків між кластерами.

Третій етап. Здійснення експертних оцінювань в кожному кластері за парними порівняннями між ними i отримання

нормованих пріоритетів. Ці процедури здійснюються за відомими правилами [7] відповідно до шкали парних порівнянь від 2 до 9 у випадку прямої переваги і від $1 / 2$ до $1 / 9$ у випадку зворотної. Результати парних порівнянь являють собою матрицю порівнюваних значень, пріоритети елементів яких отримують за формулами:

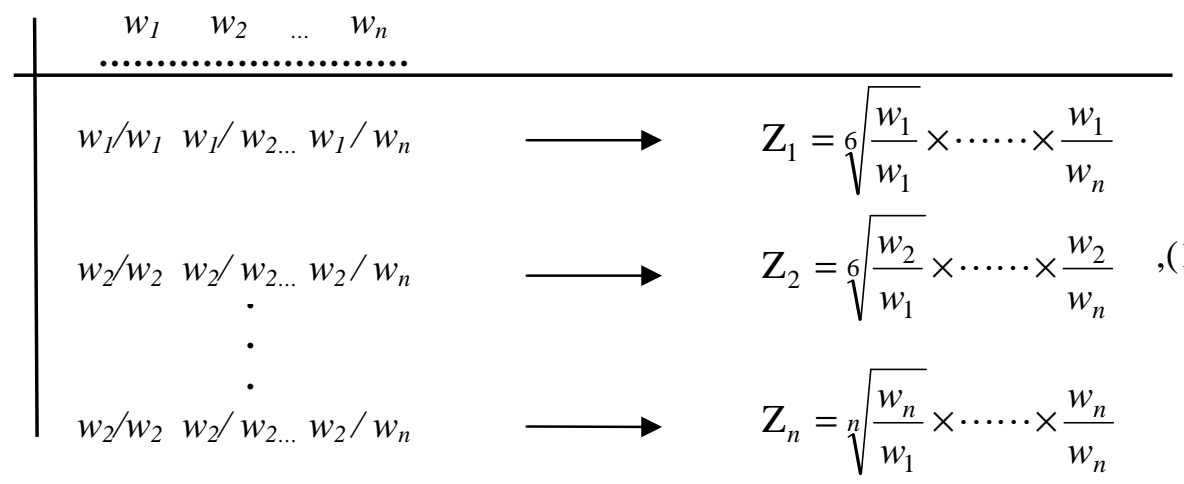

де $w_{l} / w_{1}, w_{l} / w_{2, \ldots,}, w_{n} / w_{n}$ - експертні судження парних порівнянь, отримані відповідно до шкали, табл. 1 . 
Таблиця 1

Шкала для здійснення парних порівнянь

\begin{tabular}{|c|c|l|c|}
\hline № & $\begin{array}{c}\text { Значення } \mathrm{w}_{1} / \mathrm{w}_{1}, \mathrm{w}_{1} / \mathrm{w}_{2, \ldots,} \\
\mathrm{w}_{6} / \mathrm{w}_{6}\end{array}$ & \multicolumn{1}{|c|}{ Визначення експертних суджень } & Приклад \\
\hline 1 & 1 & Рівна важливість $w_{i} \mathrm{Ta} w_{\mathrm{j}}$ & $w_{l=} w_{2}$ \\
\hline 2 & 3 & Помірна перевага $w_{i}$ над $w_{j}$ & $w_{l}>w_{2}$ \\
\hline 3 & 5 & Істотна перевага $w_{i}$ над $w_{j}$ & $w_{l}>w_{2}$ \\
\hline 4 & 7 & Значна перевага $w_{i}$ над $w_{j}$ & $w_{l}>w_{2}$ \\
\hline 5 & 9 & Максимальна перевага $w_{i}$ над $w_{j}$ & $w_{l>>} w_{2}$ \\
\hline 6 & $2,4,6,8$ & Проміжні значення між судженнями & $w_{l}>w_{2}$ \\
\hline 7 & $1 / 2,1 / 3,1 / 4,1 / 5,1 / 6, / 7,1 / 8,1 / 9$ & Значення, якщо $w_{i}$ переважає $w_{j}$ & $w_{l<} w_{2, \ldots, \ldots}, w_{l<<} w_{2}$ \\
\hline
\end{tabular}

Значення $Z_{1}, \ldots, Z_{\mathrm{n}}$ нормуються. Таким чином, для кожної матриці мережі, рис. 2, визначаються нормовані пріоритети кластерів, які розміщуються в так званій суперматриці [5]. Вигляд такої суперматриці для розглядуваного прикладу наведено у табл. 2.

Таблиця 2

Вихідна суперматриця для приклада, наведеного в статті

\begin{tabular}{|c|c|c|c|c|c|c|c|c|c|c|c|c|c|c|c|c|c|c|c|}
\hline & Ie & $\mathbf{C y}$ & $\mathbf{K}$ & Від & $\mathbf{M}$ & C & B & O & H & $\mathbf{B i}$ & Об & Д & Кб & $\Phi$ & Вб & $\mathbf{P}$ & CB & $\boldsymbol{I}$ & 3 \\
\hline $\mathrm{He}$ & 00 & 0,00 & 0,00 & 0,00 & 0,00 & 0,00 & 0,00 & 0,00 & 0,00 & 0,00 & 0,00 & 0,00 & 0,00 & 0,00 & 0,00 & 0,00 & 0,00 & 0,00 & 0,00 \\
\hline $\mathrm{Cy}$ & 00 & $\overline{00}$ & $\overline{00}$ & 00 & 0,00 & 2 & 0,00 & 0,00 & 800 & 0,00 & 0,00 & 0,00 & 0,00 & 0,00 & 8 & 00 & 00 & 00 & 0,00 \\
\hline $\mathrm{K}$ & 0 & 00 & 0,00 & 0,00 & 0,00 & 0,00 & 0,00 & 0,00 & 0,00 & 0,00 & 0,00 & 0,00 & 0,0 & 0,00 & 00 & 00 & 0 & 0 &, 00 \\
\hline $\mathrm{B12}$ & & & & 0,00 & 0,00 & 0,00 & 0, & 0,00 & 0,00 & 0,00 & 0,00 & 0,00 & 0, & 0,00 & 0,00 & 0 &, 00 & 0 &, 00 \\
\hline $\mathrm{M}$ & 2 & $=0$ & $\overline{0}$ & $0,0 \mathrm{C}$ & 0,0 & 00 & 0,00 & 00 & 00 & 0,00 & 0,00 & 0,00 & & & & & & & 00 \\
\hline 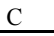 & 21 & 44 & 0,3 & 0,00 & 0,00 & 00 & 0,00 & 00 & 00 & 0,00 & 0,00 & 0,00 & & & & & & & 00 \\
\hline $\mathrm{D}$ & 0 & 0,00 & 0,00 & $\begin{array}{l}0,49 \\
\end{array}$ & 0,58 & 0,64 & 0,00 & 0,00 & 0,00 & 0,14 & 0,10 & 0,08 & 0,1 & 0,41 & 0,52 & & & 00 & 00 \\
\hline 7 & & 0,00 & 0,00 & $\begin{array}{l}0,31 \\
\end{array}$ & 0,28 & 0,26 & 0,00 & 0,00 & 0,00 & \begin{tabular}{c|}
0,28 \\
\end{tabular} & 0,26 & 0,23 & 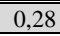 & 0,33 & 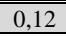 & 0,00 & & 00 &, 00 \\
\hline H & & 0,0 & 0,0 & 0,2 & 0,14 & 0,10 & 0,0 & 0,0 & 0,00 & 0,5 & 0,64 & 0,69 & & 0, & 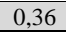 & 00 & & 00 & 0,00 \\
\hline $\mathrm{Bi}$ & & 0,0 & 0,00 & 0,0 & 0,00 & 0,00 & 0,0 & 0,0 & 0,00 & 0,0 & 0,00 & 0,00 & 0,0 & 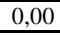 & 0,00 & 0,41 & 0,3 &, 54 & 0,17 \\
\hline Об & & 0,0 & 0,0 & 0,0 & & 0,00 & $0, \mathrm{C}$ & 0,0 & 00 & 0,0 & 0,00 & 0,00 & & & & $=$ & & 30 &, 48 \\
\hline Д & 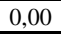 & 0,00 & 0,00 & 0,00 & 0,00 & 0,00 & 0,00 & 0,00 & 0,00 & 0,00 & 0,00 & 0,00 & 0,00 & 0,00 & 0,00 & 0,26 & 0,33 & 0,16 & 0,35 \\
\hline Кб & 0,00 & 0,00 & 0,00 & 0,00 & 0,00 & 0,00 & 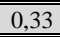 & 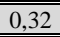 & 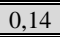 & 0,00 & 0,00 & 0,00 & 0,0 & , 00 & 00 & $\overline{00}$ & 0 & 00 & $\overline{0,00}$ \\
\hline$\Phi$ & & 0,0 & 0,00 & 0,0 & 0, & 0,00 & 0,2 & & 0,75 & 0, & 0,00 & 0,00 & & & & & & &, 00 \\
\hline Вб & & & & 00 & 0,0 & 0,00 & 0.4 & 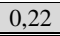 & 0.11 & 0,0 & 0,00 & 0,00 & 0 & & & & & &, 00 \\
\hline 1 & 0,00 & 0,0 & 0,0 & 0,4 & $\overline{0.3}$ & 0,30 & 0,3 & $\overline{0,3}$ & 0,29 & 0,48 & 0,39 & 0,38 & 0, & 0, & $\overline{0,2}$ & 0 & & 0 &, 00 \\
\hline $\mathrm{CB}_{\mathrm{B}}$ & 0,00 & 0,00 & 0,00 & 0,31 & 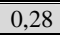 & 0,25 & $\begin{array}{ll}0,33 \\
\end{array}$ & 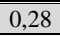 & 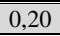 & 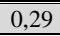 & 0,30 & 0,35 & 0 , & 0,2 & 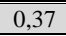 & 0 & & 00 & 0,00 \\
\hline Л & 0,00 & 0,00 & 0,00 & 0,12 & 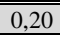 & 0,25 & $\begin{array}{ll}0,17 \\
\end{array}$ & 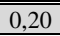 & 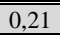 & 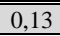 & $\begin{array}{lll}0,17 \\
\end{array}$ & \begin{tabular}{|l|l|}
0,13 \\
\end{tabular} & $\overline{\overline{0} 0,}$ & 0,23 & 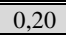 & 0,00 & 0,00 & 00 & 0,00 \\
\hline 3 & 0,00 & 0,00 & 0,00 & 0,16 & 0,14 & 0,21 & 0,17 & 0,14 & 0,21 & 0,10 & 0,14 & \begin{tabular}{|l|l|}
0,14 \\
\end{tabular} & 0,1 & 0,1 & 0,15 & 0,00 & 0,0 & 0,00 & 0,00 \\
\hline
\end{tabular}

Четвертий етап. Проведення розрахунків. Розрахунки за вихідною суперматрицею можна здійснювати за допомогою спеціалізованої програми ExpertChoce [8] (англійською мовою), але доцільніше використати стандартну програму Microsoft Excel, яка хоч і $€$ більш трудомісткою, але $\epsilon$ безкоштовною та дає змогу проводити аналогічні обчислення i контролювати результати. За наведеним прикладом проведено обчислення, вихідними даними для яких були судження самих авторів статті. Результат цих обчислень наведено у табл. 3.

Таблиця 3

Результат обчислень за вихідною суперматрицею

\begin{tabular}{|c|l|l|l|l|l|l|l|l|l|}
\hline & $\mathbf{H}$ & $\mathbf{C y}$ & $\mathbf{K}$ & $\mathbf{B i д}$ & $\mathbf{M}$ & $\mathbf{C}$ & $\mathbf{B}$ & $\mathbf{O}$ & $\mathbf{H}$ \\
\hline $\mathbf{H е}$ & 0,00 & 0,00 & 0,00 & 0,00 & 0,00 & 0,00 & 0,00 & 0,00 & 0,00 \\
\hline $\mathbf{C y}$ & 0,00 & 0,00 & 0,00 & 0,00 & 0,00 & 0,00 & 0,00 & 0,00 & 0,00 \\
\hline $\mathbf{K}$ & 0,00 & 0,00 & 0,00 & 0,00 & 0,00 & 0,00 & 0,00 & 0,00 & 0,00 \\
\hline Від & 0,00 & 0,00 & 0,00 & 0,00 & 0,00 & 0,00 & 0,00 & 0,00 & 0,00 \\
\hline $\mathbf{M}$ & 0,00 & 0,00 & 0,00 & 0,00 & 0,00 & 0,00 & 0,00 & 0,00 & 0,00 \\
\hline $\mathbf{C}$ & 0,00 & 0,00 & 0,00 & 0,00 & 0,00 & 0,00 & 0,00 & 0,00 & 0,00 \\
\hline $\mathbf{В}$ & 0,039 & 0,039 & 0,039 & 0,039 & 0,039 & 0,039 & 0,039 & 0,039 & 0,039 \\
\hline $\mathbf{O}$ & 0,059 & 0,059 & 0,059 & 0,059 & 0,059 & 0,059 & 0,059 & 0,059 & 0,059 \\
\hline $\mathbf{H}$ & 0,125 & 0,125 & 0,125 & 0,125 & 0,125 & 0,125 & 0,125 & 0,125 & 0,125 \\
\hline $\mathbf{В i}$ & 0,130 & 0,130 & 0,130 & 0,130 & 0,130 & 0,130 & 0,130 & 0,130 & 0,130 \\
\hline Об & 0,111 & 0,111 & 0,111 & 0,111 & 0,111 & 0,111 & 0,111 & 0,111 & 0,111 \\
\hline Д & 0,093 & 0,093 & 0,093 & 0,093 & 0,093 & 0,093 & 0,093 & 0,093 & 0,093 \\
\hline Кб & 0,024 & 0,024 & 0,024 & 0,024 & 0,024 & 0,024 & 0,024 & 0,024 & 0,024 \\
\hline $\mathbf{\Phi}$ & 0,065 & 0,065 & 0,065 & 0,065 & 0,065 & 0,065 & 0,065 & 0,065 & 0,065 \\
\hline Вб & 0,022 & 0,022 & 0,022 & 0,022 & 0,022 & 0,022 & 0,022 & 0,022 & 0,022 \\
\hline $\mathbf{P}$ & 0,127 & 0,127 & 0,127 & 0,127 & 0,127 & 0,127 & 0,127 & 0,127 & 0,127 \\
\hline Св & 0,100 & 0,100 & 0,100 & 0,100 & 0,100 & 0,100 & 0,100 & 0,100 & 0,100 \\
\hline Л & 0,058 & 0,058 & 0,058 & 0,058 & 0,058 & 0,058 & 0,058 & 0,058 & 0,058 \\
\hline
\end{tabular}




\begin{tabular}{l|l|l|l|l|l|l|l|l|l|}
3 & 0,048 & 0,048 & 0,048 & 0,048 & 0,048 & 0,048 & 0,048 & 0,048 & 0,048 \\
\hline
\end{tabular}

\begin{tabular}{|c|c|c|c|c|c|c|c|c|c|c|}
\hline & $\mathbf{B i}$ & Об & Д & Кб & $\Phi$ & Вб & $\mathbf{P}$ & CB & I & 3 \\
\hline $\mathrm{He}$ & 0,00 & 0,00 & 0,00 & 0,00 & 0,00 & 0,00 & 0,00 & 0,00 & 0,00 & 0,00 \\
\hline Cy & 0,00 & 0,00 & 0,00 & 0,00 & 0,00 & 0,00 & 0,00 & 0,00 & 0,00 & 0,00 \\
\hline $\mathbf{K}$ & 0,00 & 0,00 & 0,00 & 0,00 & 0,00 & 0,00 & 0,00 & 0,00 & 0,00 & 0,00 \\
\hline Від & 0,00 & 0,00 & 0,00 & 0,00 & 0,00 & 0,00 & 0,00 & 0,00 & 0,00 & 0,00 \\
\hline M & 0,00 & 0,00 & 0,00 & 0,00 & 0,00 & 0,00 & 0,00 & 0,00 & 0,00 & 0,00 \\
\hline $\mathrm{C}$ & 0,00 & 0,00 & 0,00 & 0,00 & 0,00 & 0,00 & 0,00 & 0,00 & 0,00 & 0,00 \\
\hline B & 0,039 & 0,039 & 0,039 & 0,039 & 0,039 & 0,039 & 0,039 & 0,039 & 0,039 & 0,039 \\
\hline O & 0,059 & 0,059 & 0,059 & 0,059 & 0,059 & 0,059 & 0,059 & 0,059 & 0,059 & 0,059 \\
\hline $\mathbf{H}$ & 0,125 & 0,125 & 0,125 & 0,125 & 0,125 & 0,125 & 0,125 & 0,125 & 0,125 & 0,125 \\
\hline $\mathbf{B i}$ & 0,130 & 0,130 & 0,130 & 0,130 & 0,130 & 0,130 & 0,130 & 0,130 & 0,130 & 0,130 \\
\hline Об & 0,111 & 0,111 & 0,111 & 0,111 & 0,111 & 0,111 & 0,111 & 0,111 & 0,111 & 0,111 \\
\hline Д & 0,093 & 0,093 & 0,093 & 0,093 & 0,093 & 0,093 & 0,093 & 0,093 & 0,093 & 0,093 \\
\hline Кб & 0,024 & 0,024 & 0,024 & 0,024 & 0,024 & 0,024 & 0,024 & 0,024 & 0,024 & 0,024 \\
\hline$\Phi$ & 0,065 & 0,065 & 0,065 & 0,065 & 0,065 & 0,065 & 0,065 & 0,065 & 0,065 & 0,065 \\
\hline Вб & 0,022 & 0,022 & 0,022 & 0,022 & 0,022 & 0,022 & 0,022 & 0,022 & 0,022 & 0,022 \\
\hline $\mathbf{P}$ & 0,127 & 0,127 & 0,127 & 0,127 & 0,127 & 0,127 & 0,127 & 0,127 & 0,127 & 0,127 \\
\hline Cв & 0,100 & 0,100 & 0,100 & 0,100 & 0,100 & 0,100 & 0,100 & 0,100 & 0,100 & 0,100 \\
\hline Л & 0,058 & 0,058 & 0,058 & 0,058 & 0,058 & 0,058 & 0,058 & 0,058 & 0,058 & 0,058 \\
\hline 3 & 0,048 & 0,048 & 0,048 & 0,048 & 0,048 & 0,048 & 0,048 & 0,048 & 0,048 & 0,048 \\
\hline
\end{tabular}

Відповідно до цього результату за гіпотетичним зразком ВТ пріоритет має альтернатива розроблення і подальше виробництво нового зразка в Україні, рис. 3.

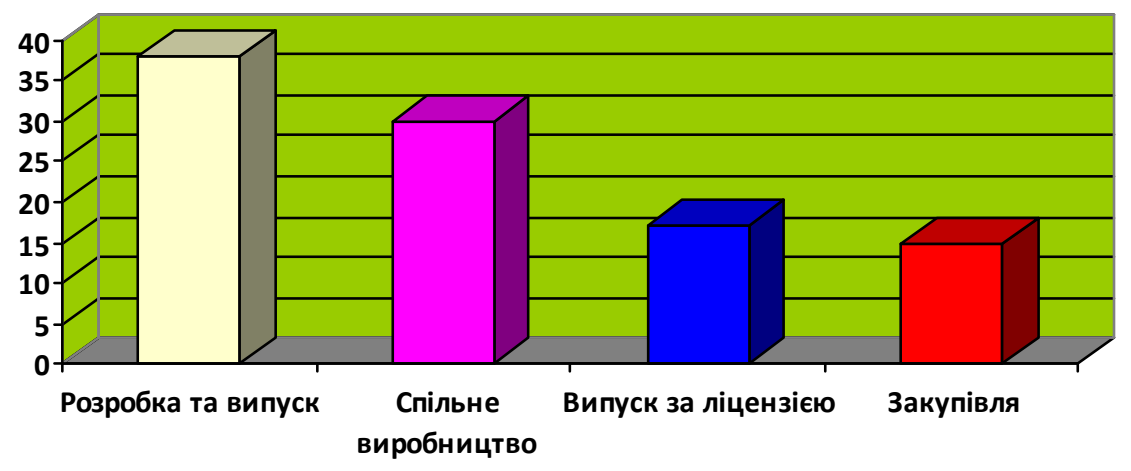

Рис. 3

Хоча пріоритет зазначеної альтернативи не $є$ безумовним, вона переважає найближчий за значенням варіант - спільне 3 іншою країною розроблення i виробництво нового зразка в Україні понад $8 \%$.

П'ятий етап. Аналіз отриманого результату i формулювання висновків. В окремих випадках результат може бути неоднозначним (наприклад, коли значення пріоритетів альтернатив майже однакові). Тоді необхідно переглянути або вихідні дані, або чіткіше сформувати саму мережу (можливо окремі зв'язки були упущені або некоректно встановлені).

Висновки. Запропонований підхід дає змогу вирішити ряд питань воєнно-технічної політики, а саме:

описати вихідні дані 3 урахуванням умов щодо фінансування, виробництва, закупівлі та інших складових, що обумовлюють забезпечення ЗС України новими зразками ВТ; врахувати такі важливі чинники, як вплив воєнно-технічної політики інших держав на розвиток ВТ та зміни в збройній боротьбі;

використати як якісні, так і кількісні характеристики оцінювання умов забезпечення ВТ Збройних Сил.

Застосування подібного підходу до оцінки різних зразків ВТ, яких потребують ЗС України дасть змогу використовувати під час короткострокового i середньострокового планування, враховуючи, перш за все, фінансові можливості держави.

Подальші дослідження доцільно присвятити розробленню методик за окремими воєнно-технічними напрямами. Зокрема, в умовах проведення антитерористичної операції до таких напрямів відносяться - розроблення техніки зв'язку, поліпшених телекомунікаційних засобів, засобів ведення бойових дій в нічних умовах, протитанкових та артилерійських систем та автомобільної техніки [9]. 


\section{СПИСОК ВИКОРИСТАНОЇ ЛІТЕРАТУРИ}

1. Арепин Ю. И. Военно-економическое обоснование развития вооружения и военной техники. Режим доступу: http://elibrary.ru/item.asp?id=11685565

2. Полегенько А. Ф. Методика вибору значень часткових показників якості до перспективного зразка озброєння і військової техніки // Збірник наукових праць Військового інституту Київського національного університету імені Тараса Шевченка. - Вип. №14 - К.: ВІКНУ, 2008. - C.101-107.

3. Маричев П. А., Мушков А. Ю., Рымкевич С. Н. Военно-економическое обоснование выбора варианта развития вооружения и военной техники противовоздушной обороны. Режим доступу: http://elibrary.ru/item.asp?id=15123759

4. В. Цымбал, И. Терехов США: опыт перехода на интенсивный путь развития вооружений и военной техники. Режим

http://www.rau.su/observer/№28_93/28_13/HTM

5. Thomas L.Saaty Decision Making with Dependence and Feedback: The Analytik Network Process//Thomas

L Saaty University of Pittsburg 322 Mervis Hall Pittsburg, PA. -357 p.

6. Принятие решений при зависимостях и обратных связях [Текст]: аналитические сети / Т. Л. Саати; пер. О. Н. Андрейчикова; ред.: О. Н. Андрейчиков. М.: ЛКИ, 2008. - 307 с.

7. Саати Т, Кернс К. Аналитическое планирование. Организация систем: Пер. с англ. - М. Радио и связь, 1991. - С.32

8. ExpertChoce for Collaborative Decision Making Режим доступу: http://expertchoce.com/

9. Яка українська армія сьогодні - оцінка начальника Генерального штабу ЗС України. Режим доступу: http://www.milnavigator.com/uk/yakaukra\%D1\%97nska-armiya-sogodni-ocinka-nachalnikageneralnogo-shtabu-zs-ukra\%D1\%97ni/

Стаття надійшла до редакції 31.01.2017

Станович А. В. ${ }^{1}$;

Клевко П. В. ${ }^{1}$;

Цимбал И. В. ${ }^{1}$;

Плуговая О. Б. ${ }^{1}$;

Троцько Л. Г. ${ }^{1}$;

Ворона Т. А. ${ }^{2}$

1 - Военный институт телекоммуникаций и информатизации, Киев;

- Центр военно-стратегических исследований Национального университета обороны Украины имени Ивана Черняховского, Киев

Методический подход к обоснованию рационального варианта обеспечения Вооружённых Сил Украины новыми образцами военной техники в современных условиях

Резюме. В статье предложен подход к выбору варианта обеспечения новыми образцами военной техники для оснащения Вооружённых Сил Украины с учетом влияния ряда системных факторов. В качестве способа оценивания вариантов предложен метод анализа сетей (AHP-process).

Ключевые слова: методический подход, военная техника, Вооружённые Силы Украины, метод анализа сетей (AHP-process), антитеррористическая операция.

O. Stanovych ${ }^{1}$;

P. Klevko ${ }^{1}$;

I. Tsymbal ${ }^{1}$;

O. Plugova ${ }^{1}$;

L. Trotsko ${ }^{1}$;

T. Vorona ${ }^{2}$

1 - Military institute of telecommunications and informatization, Kyiv;

2 - Center for Military and Strategic Studies National Defence University of Ukraine named after Ivan Chernyhovsky, Kyiv

The methodical approach for explaining the rational variant of ensuring armed forces of Ukraine by new samples of military technique in the modern conditions

Resume. In the article offered approach near the choice of variant of providing the new standards of military technique for the equipment of the Armed Forces of Ukraine taking into account influence of row of system factors. As a method of evaluation of variants there is the offered method of analysis of networks (AHPprocess).

Keywords: methodical approach, military technique, Armed Forces of Ukraine, method of analysis of networks (AHP-process), anti-terror operation. 